\title{
A Review of Root Barrier Research
}

\author{
Justin Morgenroth
}

\begin{abstract}
A review of root barrier research from the past 40 years is presented. Research has resulted from the need to minimize conflicts between the expanding roots of trees and urban infrastructure such as roads, curbs, sidewalks, foundations, and underground utilities. The history of root barriers, naming conventions, and different classes are described. The results of experiments and surveys are examined, the successes and failures of different barriers are noted, and directions for future research are suggested.

Key Words. Curbs; infrastructure conflicts; roads; root barriers; roots; sidewalks; street trees; urban trees.
\end{abstract}

\section{THE NEED FOR ROOT BARRIERS}

It is widely acknowledged that the roots of street trees in urban areas conflict with hardscape such as roads, sidewalks, and curbs. Damage to hardscape is internationally pervasive, affecting regions as diverse as North America (Wagar and Barker 1983; D'Amato et al. 2002a; Rajani 2002), Central America (Benavides Meza 1992; Francis et al. 1996), South America (Achinelli et al. 1997), and Europe (Wong et al. 1988; Kopinga 1994; Reichwein 2002). The mechanisms that result in conflict remain unclear. Some researchers argue that sidewalks induce root growth (D'Amato et al. 2002b). This is plausible given that soils directly beneath sidewalks possess better moisture and temperature regimes than surrounding soils (Craul 1992; Wagar and Franklin 1994). In contrast, most studies suggest that trees are the root of the problem. Perhaps this stems from the common observation that cracked or heaved sidewalks are often adjacent to trees and that roots are often located directly beneath cracks (Nicoll and Armstrong 1998). Sydnor et al. (2000) dispute this, reporting the incidence of cracks in sidewalks is not related to the presence of adjacent trees.

Irrespective of the cause of the conflict, the resulting cracking and heaving of sidewalks and roads is highly undesirable. In addition to being aesthetically displeasing, heaved sidewalks are a safety liability and impose accessibility restrictions. The conflicts are so pervasive that millions of dollars from urban forestry budgets are spent on mitigation and remediation annually (McPherson and Peper 1995). A tree-friendly approach to minimizing the inherent conflicts between street tree roots and adjacent hardscape is desperately needed because current solutions too often result in damage to, or even removal of, street trees and thus degradation of the urban forest. One potential solution is the root barrier. This review provides the reader with an understanding of root barrier-related research conducted to date.

\section{ROOT BARRIER CLASSES}

Numerous researchers have suggested that root barriers are a potential solution to the conflicts between green and gray infrastructure (e.g., Hamilton 1984; Coder 1998; Randrup et al. 2001), although this is not universally accepted (e.g., Mead 1994). Root barriers are a physical or chemical impediment intended to limit root growth to designated areas away from infrastructure. There are three main classes of root barrier: traps, inhibitors, and deflectors (Coder 1998).
Traps do not entirely inhibit root growth. Instead, they allow root tips to penetrate small holes, but subsequently preclude radial growth by girdling. Examples are woven nylon or copper screen, which are permeable and, as such, allow for lateral water movement and gas exchange (Coder 1998). A potential disadvantage to this type of barrier is that by severely restricting large root development in one or more directions, traps may predispose trees to instability.

Inhibitors are used to control root growth by means of chemical intervention. Many of these barriers consist of fabric impregnated with a slowly released herbicide. Commonly, the herbicide used is trifluralin, which is considered to have no detrimental environmental impact beyond the root control area (Van Voris et al. 1988). As root tips approach the barrier, cell division is impeded and thus root growth is controlled.

Deflectors, often constructed from plastics, are physical impediments to root growth. They function by redirecting root growth away from infrastructure. Initial lateral root growth is deflected downward when roots come into contact with the barrier. In theory, by forcing roots to grow at depth, the forces that they exert will dissipate through a larger volume of soil before reaching the sidewalks above. This class of barrier is ideally suited for use adjacent to roads or sidewalks. Given their impermeability, these barriers may impact air and water movement throughout the soil profile.

Each of these three barrier types can be configured linearly or circularly. Linear barriers are installed in narrow trenches along the edge of a desired protection zone such as a sidewalk or curb (Figure 1). Alternatively, circular barriers are installed around the rootball of a newly planted tree (Figure 2). This circular configuration is often used in street tree pits or other restrictive spaces (Randrup et al. 2001). Linear configurations are more flexible because they can be used near new or existing trees. Conversely, circular configurations are used only for new plantings.

One further distinction this author suggests is between twodimensional barriers and three-dimensional barriers. The former is a vertically placed barrier extending downward, perpendicular to the soil surface. The latter will fill a three-dimensional volume underneath the surface it is intended to protect (Figure 3). An example of three-dimensional barriers is the coarse gravel subbase tested by Gilman (2006). Three-dimensional barriers have also been referred to as air gaps (Coder 1998). 


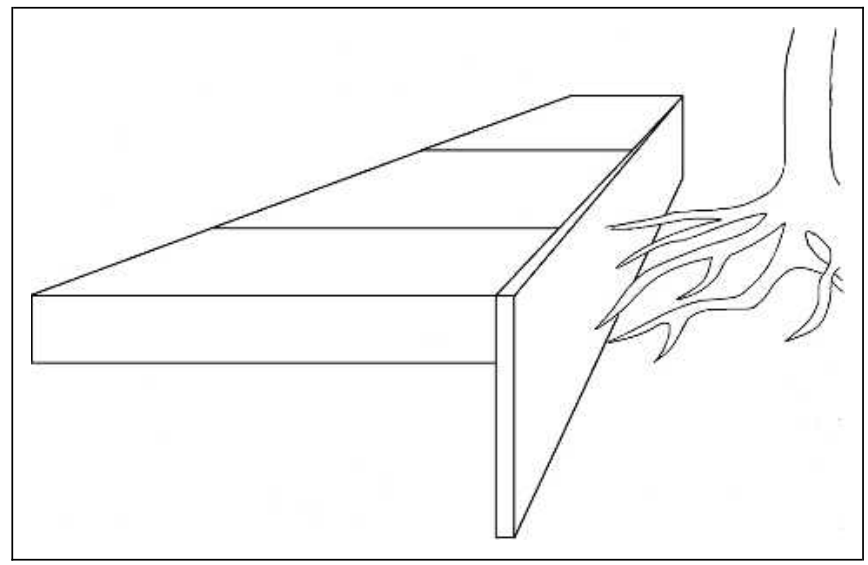

Figure 1. A linear root barrier.

\section{HISTORY OF ROOT BARRIERS}

Roots cause both direct and indirect damage to infrastructure. Direct damage is related to the forces exerted by expanding roots and typically affects only light infrastructure such as roads, curbs, and sidewalks. Indirect damage is associated with soil movement resulting from changes in moisture content precipitated by roots. In cases of indirect damage, concrete cutoff walls prevent root growth in undesired areas. A typical application of cutoff walls is to exclude roots from soils near the foundations of buildings. This is necessary because root moisture absorption causes soil shrinking and differential settling, which causes significant structural damage to foundations and walls. Cutoff walls are especially prevalent in areas characterized by plastic clays such as London, U.K. They are installed by digging deep trenches between trees and the desired protection area. These trenches, often many meters deep, are filled with concrete slurry, thus creating a subterranean wall. In extreme cases, cutoff walls are secured to the bedrock.

In cases of direct damage, tree roots affect roads, curbs, and sidewalks. To prevent root growth near these elements of infrastructure on a city scale, concrete cutoff walls are impractical and so other means are necessary. To address this large-scale need for root management, commercial root barriers were developed during the 1970s (Randrup et al. 2001). Since then, their use has risen substantially. A survey of 137 cities in California has shown that confidence in root barriers rose markedly during the 1990s; the percentage of respondents who believed linear and circular barriers were effective rose to $52 \%$ and $40 \%$, respectively. By contrast, the belief that inhibitor-style barriers are effective has declined to 33\% (Thompson 2006).

Formal root barrier studies have been conducted for approximately 40 years, dating back to Wilson (1967) who studied root behavior after contact with simulated barriers. He noted that there appeared to be little tendency for roots to become trained to the direction of the barrier. This was the first evidence of the difficulties inherent in attempting to control root growth.

\section{ROOT BARRIER DESIGN}

Root barrier designs have changed over time and although differences in design are often subtle, they can be the difference between an effective and ineffective barrier. Many barriers cause roots to circle, thus precipitating the introduction of vertical ribs to deflect root growth downward. Whole barriers were heaved

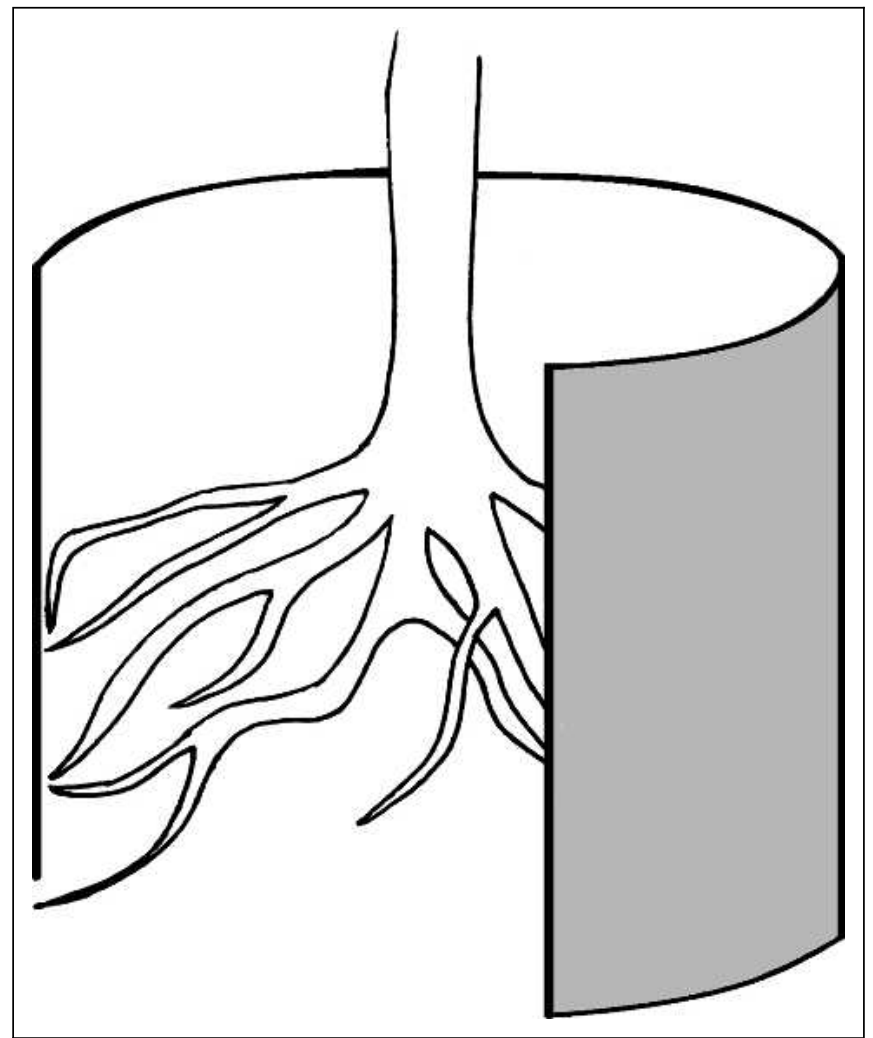

Figure 2. A circular root barrier.

upward by soil movement over time, so new designs have incorporated wings or tabs meant to lock the barriers in place. The connectors used to join segments of root barriers are a challenging design consideration; if they fail, roots will penetrate the gap in the barrier. Some designs incorporate a separate connector, some use a chemical bonding agent, and others still have integrated couplings. The top edge of barriers, which is aboveground level, has been observed to deteriorate rapidly as a result of pedestrian and vehicular damage. Some newer barriers have incorporated a wide, rugged upper edge to combat this issue. These and other practical differences were reviewed and contrasted by Barker and Peper (1995) who identified vertical ribs, durability, ease of installation, connector type, and material type as crucial characteristics of effective barrier design.

In addition to the commercial options, numerous "homemade" versions have been tested. These include polyethylene tubing,

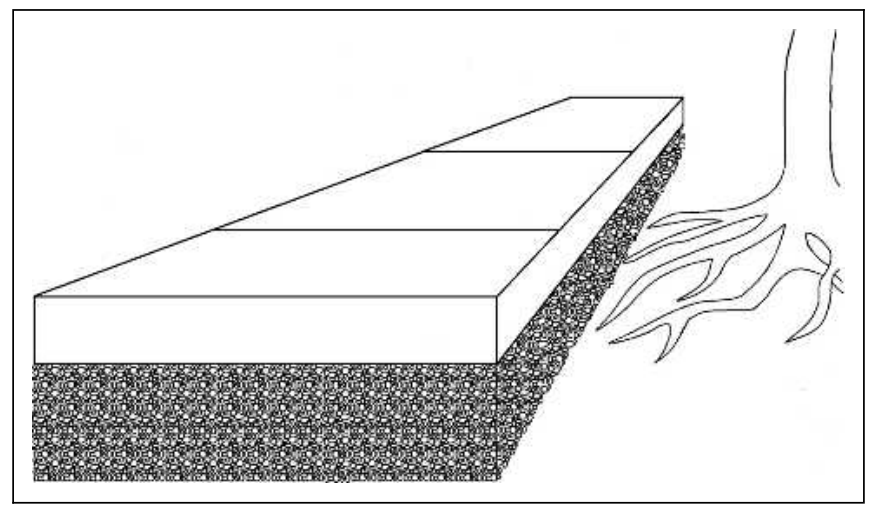

Figure 3. A three-dimensional root barrier. 
polyvinyl chloride planter boxes, nylon fabric, copper screen, Typar $^{\circledR}$ fabric (DuPont, Summerville, SC), and coarse gravel. Although these options are not purpose-built, some have proven successful, in particular coarse gravel (Gilman 2006).

\section{SUMMARY OF ROOT BARRIER RESEARCH}

After initial root barrier studies during the early 1980s, publications increased substantially during the mid to late 1990s, mirroring their increased popularity. Despite over 20 years of study, relatively few articles describing root barriers have been published to date, likely the consequence of the high costs and long timeframes associated with belowground experiments. Despite this, the published studies have successfully described root barriers and their uses, contrasted the practical application and effectiveness of different classes and types of barriers, and exposed some important limitations to their use.

Introductory articles on the topic of root barriers are abundant (e.g., Hamilton 1984; Urban 1995; Nicoll and Coutts 1997; Coder 1998; Randrup et al. 2001). These articles are geared toward practitioners or managers looking for a solution to the conflicts between sidewalks and roots. The articles provide the reader with a description of the need for root barriers, the different classes of barriers, the benefits and drawbacks of their use, and their potential applications.

In addition to these overviews, numerous experiments have been conducted to test the effectiveness of root barriers under controlled conditions. Most have tested barriers on newly planted trees (e.g., Wagar 1985; Knight et al. 1992; Barker 1995a, 1995b; Gilman 1996; Costello et al. 1997; Peper 1998; Peper and Mori 1999; Gilman 2006), but some have tested the effectiveness of barriers on established trees (e.g., Wagar and Barker 1993). The results generally support the assertion made by Wagar (1985) and supported by others (Urban 1995; Gilman 2006) that barriers are perhaps least effective where they are most needed. This sentiment implies that barriers are effective in well-drained, noncompacted soils, which are virtually nonexistent in roadside urban areas.

Interestingly, the experiments undertaken have resulted in differing and often opposing root responses to barriers, thus highlighting the variability of root growth and its sensitivity to soil conditions. Although some studies have detailed the effectiveness of root barriers, others have drawn attention to their inadequacy. A closer look at the measurements conducted, the barriers tested, and the site conditions elucidate some of the reasons for the reported discrepancies.

In all experiments, root response quantification has been limited to measurements of root biomass, number, diameter, and depth. Of the four root measurement parameters, only root dry weight was consistently lower for trees treated with barriers (Wagar 1985; Barker 1995a, 1995b; Peper 1998; Peper and Mori 1999). Interestingly, two studies on the same site, using the same barriers (DeepRoot ${ }^{\circledR}$ [Deep Root Partners LP, San Francisco, CA] and Tree Root Planter ${ }^{\circledR}$ [Bumble Bee Products, Signal Hill, CA]), reported different results with respect to dry root weight. Peper (1998) found that the dry root weight of mulberry (Morus alba) decreased as affected by the root barriers, whereas Peper and Mori (1999) reported that the change in dry root weight of hackberry (Celtis sinensis) was insignificant when compared with controls. This points to a species-specific response to root barrier use, a phenomenon noted by Wagar (1985) and Costello et al. (1997).
Only extreme conditions resulted in decreased root diameter for trees treated by root barriers. For example, root barriers 60 $\mathrm{cm}$ (24 in) in depth significantly reduced mean root diameter relative to controls; however, $30 \mathrm{~cm}$ (12 in) barriers had no effect (Peper 1998). Mean root diameter was also significantly less than controls, but only when rootballs were encased in a tight polyethylene tube measuring only $18 \mathrm{~cm}$ (7.2 in) in diameter as compared with the $61 \mathrm{~cm}$ (24.4 in) diameter of DeepRoot ${ }^{\circledR}$ or Tree Root Planter ${ }^{\circledR}$ (Peper and Mori 1999). Another experiment detected root diameter decrease for trees treated with gravel root barriers, but not for any two-dimensional barriers relative to controls (Gilman 2006). Apart from these examples, mean root diameter has been found not to change relative to controls by numerous authors (e.g., Costello et al. 1997; Peper 1998; Peper and Mori 1999; Gilman 2006). Perhaps the take-home message from these studies is that to affect significant changes in root diameter, typical two-dimensional, $30 \mathrm{~cm}$ (12 in) deep barriers are insufficient.

Quantifying root number yielded highly variable results influenced by species, barrier type, and soil type. A species effect was evident when the mean number of ash (Fraxinus oxycarpa) roots did not vary with respect to controls; however, poplar (Populus nigra 'Italica') roots were reduced significantly (Costello et al. 1997). A barrier-type effect occurred when the root penetration of Red maple (Acer rubrum) and American sycamore (Platanus occidentalis) treated by an inhibitor were significantly lower than controls, but roots of the same species did not differ from controls when treated with a trap (Knight et al. 1992). Finally, a soil type effect was noted by Gilman (2006) who observed similar root numbers were observed across treatments in welldrained soils but significantly decreased root numbers in poorly drained soils. The highly variable nature of root number quantification suggests that this parameter is more highly influenced by species, barrier type, or soil type than the presence or absence of a barrier.

The effect of root barriers on mean root depth is inconclusive. The outcome of the experiments assessing this parameter were split with some finding increased mean root depth associated with barrier use (Peper 1998; Peper and Mori 1999; Gilman 2006), but others reporting no significant difference (Costello et al. 1997; Peper 1998; Gilman 2006). Interestingly, some studies found barrier-specific dependencies. For instance, $30 \mathrm{~cm}$ (12 in) deep barriers did not affect root depth; however, $60 \mathrm{~cm}$ (24 in) deep barriers did (Peper 1998). Three-dimensional barriers (gravel) did increase mean root depth, but two-dimensional barriers (polyethylene, DeepRoot ${ }^{\circledR}$ ) did not (Gilman 2006). One aspect of this relationship that is less contentious is that roots tend toward upward growth once they have passed under twodimensional barriers (Gilman 1995, 1996; Costello et al. 1997; Peper 1998; Peper and Mori 1999; Gilman 2006). Barker (1995a) observed no discernible return of roots toward the surface after downward deflection, but admitted that "continued later growth of these deepened roots eventually may be into shallower soil."

No two-dimensional barrier class (trap, deflector, inhibitor) or brand (DeepRoot ${ }^{\circledR}$, Biobarrier ${ }^{\circledR}$ [Fiberweb plc, Hickory, TN], Root Block ${ }^{\circledR}$ [Mann Made Products, Redwood City, CA], Tree Root Planter ${ }^{\circledR}$, Vespro ${ }^{\circledR}$ [Vespro Inc., San Rafael, CA], polyethylene, nylon fabric, copper screen) consistently outperforms others. Clearly, soil environment, barrier design, and tree species interact to influence the outcome of root barrier experiments. 
Given the variation in soil environments in urban areas, the choice of barrier type, if any, will need to be site-specific. To paraphrase the comments of other authors, barriers appear to be effective where they are least necessary, in loose, wellaggregated, well-aerated soils (Wagar 1985; Urban 1995; Gilman 2006).

\section{FUTURE RESEARCH}

Studies have been successful in identifying future areas of research. In terms of effectiveness, the main question that needs to be answered is whether barriers can be effective under true urban conditions. It is difficult to qualify the true nature of urban conditions, but to be sure, they are characterized by suboptimal soils, extreme environmental conditions, and heterogeneous natural and artificial ground surface types. In stark contrast to these conditions, all but one experiment has been conducted on nonlimiting soils, which generally differ greatly from urban soils. Most experimental sites were characterized as well-drained sites with loamy soil. The only exception contrasted root barrier performance on well-drained and poorly drained soils and found that root barriers function more adequately in well-drained soils (Gilman 2006). Furthermore, given the temporal limitations of the studies, most trees were irrigated and fertilized, maintenance that is not routinely provided for street trees. Finally, the trees in a great majority of experiments were surrounded by natural surfaces such as bare soil, mulch, or turf rather than concrete or other impervious surfaces that would typically border street trees. Future research is needed to contrast barrier effectiveness under difficult urban conditions.

An often overlooked area of barrier research is to determine optimal root barrier depths. This idea has been discussed since the early 1990s (Barker 1994), but actual quantification has not yet been undertaken. In fact, nearly all studies used barriers installed to approximately $30 \mathrm{~cm}$ (12 in) in depth. The only exceptions were Wagar (1985) and Peper (1998) who found that $60 \mathrm{~cm}$ (24 in) deep barriers significantly decreased mean root number, decreased mean root diameter, and increased mean root depth. There is no obvious scientific reason for the $30 \mathrm{~cm}$ (12 in) depth to have become the standard, except perhaps that the vast majority of roots are found in the top $20 \mathrm{~cm}$ (8 in) of soil (Vogt et al. 1981; Perry 1982). So theoretically, a barrier depth of 30 $\mathrm{cm}$ (12 in) should influence the majority of any tree's roots. However, many experiments have shown that barriers extending to this depth are ineffective and if "barriers installed at a given depth are not effective in good soil conditions, there is little value to installing them in poorer soils" (Peper 1998). Clearly, there is a need to approach barrier design, and in particular depth, from a scientific perspective.

Another area that requires study is determining the effect of barrier use on tree health. Given that root barriers are used to inhibit root growth or displace roots into deeper, poorer soils, it is conceivable that their use results in stress, which when compounded with difficult urban planting sites, could compromise tree establishment and survival. Many studies have measured stem diameter, but no comprehensive aboveground measurements have accompanied root distribution measurements and so no authors have been able to comment on potential negative effects to trees.

Finally, all future research should consider the meaning of "significant" reductions in root growth. Some authors have affirmed that although their results were statistically significant, they doubt whether the actual differences would be sufficient to curb conflicts. For example, Gilman (2006) reported statistically deeper root depths for trees treated by Biobarrier ${ }^{\circledR}$ contrasted against trees grown without a barrier in poorly drained soils, but noted that the actual difference was only $16 \mathrm{~mm}$ (0.64 in). On the other hand, Peper and Mori (1999) found that barriers significantly increased root depth $66 \mathrm{~cm}$ (26.4 in) from the bole as compared with controls, an actual mean depth difference of approximately $5 \mathrm{~cm}(2 \mathrm{in})$. The disparity between statistical significance and practical implications calls for clear definitions of what goals are expected to be achieved through the installation of root barriers.

In summary, root barriers are an invention bred out of necessity. Street trees inherently conflict with their surroundings and the results are highly undesirable. Over 30 years ago, barriers were first introduced and experimental research is continually shaping their design and application. Perhaps the most important finding to date has been the variability of root response to barriers seemingly influenced by soil type, environmental conditions, and species selection. Despite these challenges, future research must continue to work toward a solution that will minimize conflicts while optimizing the soil environment for root growth.

\section{LITERATURE CITED}

Achinelli, F.G., J.L. Marquina, and R.M. Marlats. 1997. Exploratory study of the relationships between tree growth, site conditions, and maintenance practices in street plantings of Fraxinus pennsylvanica marshall of La Plata City, Argentina. Arboricultural Journal 21: 305-315.

Barker, P.A. 1994. Root barriers for controlling damage to sidewalks. In Watson, G., and D. Neely (Eds.). The Landscape Below Ground. Proceedings of the International Workshop on Tree Root Development in Urban Soils. International Society of Arboriculture, Champaign, IL. pp. 179-185.

. 1995a. Managed development of tree roots. I. Ultra-deep rootball and root barrier effects on European hackberry. Journal of Arboriculture 21:202-208.

- 1995b. Managed development of tree roots II. Ultra-deep rootball and root barrier effects on Southwestern black cherry. Journal of Arboriculture 21:251-258.

Barker, P.A., and P.J. Peper. 1995. Strategies to prevent damage to sidewalks by tree roots. Arboricultural Journal 19:295-309.

Benavides Meza, H.M. 1992. Current situation of the urban forest in Mexico City. Journal of Arboriculture 18:33-36.

Coder, K. 1998. Root growth control: Managing perceptions and realities. In Neely, D., and G.W. Watson (Eds.). The Landscape Below Ground II: Proceedings of an International Workshop on Tree Root Development in Urban Soils. International Society of Arboriculture, Champaign, IL. pp. 51-81.

Costello, L.R., C.L. Elmore, and S. Steinmaus. 1997. Tree root response to circling root barriers. Journal of Arboriculture 23:211-218.

Craul, P.J. 1992. Urban Soil in Landscape Design. John Wiley \& Sons, Inc., New York, NY. 416 pp.

D'Amato, N.E., T.D. Sydnor, R. Hunt, and B. Bishop. 2002a. Root growth beneath sidewalks near trees of four genera. Journal of Arboriculture 28:283-290.

D'Amato, N.E., T.D. Sydnor, M. Knee, R. Hunt, and B. Bishop. 2002b. Which comes first, the root or the crack? Journal of Arboriculture 28:277-282.

Francis, J.K., B.R. Parresol, and J.M. De Patino. 1996. Probability of damage to sidewalks and curbs by street trees in the tropics. Journal of Arboriculture 22:193-197.

Gilman, E.F. 1995. Root barriers affect root distribution. In Watson, G., and D. Neely (Eds.). Trees and Building Sites: Proceedings of an 
International Workshop on Trees and Buildings, Chicago, IL. International Society of Arboriculture, Champaign, IL. pp. 64-67.

1996. Root barriers affect root distribution. Journal of Arboriculture 22:151-154

2006. Deflecting roots near sidewalks. Arboriculture and Urban Forestry 32:18-23.

Hamilton, D. 1984. Sidewalk/curb-breaking tree roots 2. Management to minimize existing pavement problems by tree roots. Arboricultural Journal 8:223-233.

Knight, P.R., D.J. Eakes, C.H. Gilliam, and J.A. Raeder. 1992. Root control techniques for the urban landscape. In James, B.L. (Ed.). Proceedings of the Southern Nurserymen's Association Research Conference Annual Report. Southern Nurserymen's Association, Inc., Marietta, GA. pp. 39-41.

Kopinga, J. 1994. Aspects of the damage to asphalt road pavings caused by roots. In Watson, G., and D. Neely (Eds.). The Landscape Below Ground. Proceedings of an International Workshop on Tree Root Development in Urban Soils. International Society of Arboriculture, Champaign, IL. pp. 165-178.

McPherson, G., and P.J. Peper. 1995. Infrastructure repair costs associated with street trees in 15 cities. In Watson, G.W., and D. Neely (Eds.). Trees and Building Sites: Proceedings of an International Workshop on Trees and Buildings. International Society of Arboriculture, Champaign, IL. pp. 49-63.

Mead, J.M. 1994. Trees and buildings: Insurance consequences. Arboricultural Journal 18:149-154.

Nicoll, B.C., and A. Armstrong. 1998. Development of Prunus root systems in a city street: Pavement damage and root architecture. Arboricultural Journal 22:259-270.

Nicoll, B.C., and M.P. Coutts. 1997. Direct damage by urban tree roots: Paving the way for less damaging street trees. In Claridge, J. (Eds.) Arboricultural Practice, Present and Future. Department of the Environment, Transport and the Regions, Norwich, U.K. pp. 77-84.

Peper, P.J. 1998. Comparison of root barriers installed at two depths for reduction of white mulberry roots in the soil surface. In Watson, G., and D. Neely (Eds.). The Landscape Below Ground II: Proceedings of an International Workshop on Tree Root Development in Urban Soils. International Society of Arboriculture, San Francisco, CA. pp. 82-93.

Peper, P.J., and S. Mori. 1999. Controlling root depth of post-transplant trees: Extension casing and root barrier effects on Chinese hackberry. Journal of Arboriculture 25:1-8.

Perry, T.O. 1982. The ecology of tree roots and the practical significance thereof. Journal of Arboriculture 8:197-211.

Rajani, B. 2002. Best Practices for Concrete Sidewalk Construction: Construction Technology Update \#54. Institute for Research in Construction, National Research Council of Canada, Ottawa.

Randrup, T.B., E.G. McPherson, and L.R. Costello. 2001. A review of tree root conflicts with sidewalks, curbs, and roads. Urban Ecosystems 5:209-225.

Reichwein, S. 2002. Baumwurzeln unter Verkehrsflachen: Untersuchungen zu Schaden an Verkehrsflachen durch Baumwurzeln und Ansatze zur Schadensbehelbung und Schadensvermeidung. Fachbereich Landschaftsarchitektur und Umweltentwicklung. Universitat Hannover, Hannover, Germany.

Sydnor, T.D., D. Gamstetter, J. Nichols, B. Bishop, J. Favorite, C. Blazer, and L. Turpin. 2000. Trees are not the root of sidewalk problems. Journal of Arboriculture 26:20-29.

Thompson, R.P. 2006. The State of Urban and Community Forestry in California. Urban Forest Ecosystems Institute, San Luis Obispo, CA. p. 48 .

Urban, J. 1995. Root barriers: An evaluation. Landscape Architecture. 84:28-31.
Van Voris, P., D.A. Cataldo, C.E. Cowan, N.R. Gordon, J.F. Cline, F.G. Burton, and W.E. Skeins. 1988. Long-term, controlled release of herbicides: Root growth reduction. In Cross, B. and H.B. Scher (Eds.). Pesticide Formulations: Innovations and Developments. American Chemical Society, Washington, DC. pp. 222-240.

Vogt, K.A., R.I. Edmonds, and C.C. Grier. 1981. Seasonal changes in biomass and vertical distribution of mycorrhizal and fibrous-textured conifer fine roots in 23- and 180-year old subalpine Abies amabilis stands. Canadian Journal of Forest Research 11:223-229.

Wagar, J.A. 1985. Reducing surface rooting of trees with control planters and wells. Journal of Arboriculture 11:165-171.

Wagar, J.A., and P.A. Barker. 1983. Tree root damage to sidewalks and curbs. Journal of Arboriculture 9:177-181.

- 1993. Effectiveness of three barrier materials for stopping regenerating roots of established trees. Journal of Arboriculture 19: 332-338

Wagar, J.A., and A.L. Franklin. 1994. Sidewalk effects on soil moisture and temperature. Journal of Arboriculture 20:237-238.

Wilson, B.F. 1967. Root growth around barriers. Botanical Gazette 128: 79-82.

Wong, T.W., J.E.G. Good, and M.P. Denne. 1988. Tree root damage to pavements and kerbs in the city of Manchester. Arboricultural Journal 12:17-34.

\section{Justin Morgenroth \\ School of Forestry, University of Canterbury \\ Private Bag 4800 \\ Christchurch \\ New Zealand \\ jmo101@student.canterbury.ac.nz}

Résumé. Une revue de la recherche au cours des quarante dernières années dans le domaine des barrières racinaires est présentée. La recherche est la conséquence du besoin de minimiser les conflits entre l'expansion des racines des arbres et les infrastructures urbaines telles que rues, bordures de rues, trottoirs, fondations et conduits souterrains. L'histoire des barrières racinaires, des conventions de terminologie et des différentes classes sont décrites. Les résultats des expériences et des études sont examinés, les succès et échecs des différentes barrières sont notés et des orientations pour les futures recherches sont suggérées.

Zusammenfassung. Hier wird ein Rückblick über die vergangenen 40 Jahre zum Stand der Forschung bzgl. Wurzelbarrieren vorgestellt. Die Forschung hat ergeben, dass ein Bedarf besteht in der Minimierung der Konflikte zwischen sich ausdehnenden Baumwurzeln und urbaner Infrastruktur, wie Straßen, Bordsteinen, Gehwegen, Fundamenten und Untergrund-Versorgungsleitungen. Die Geschichte von Wurzelsperren, unter näherer Bezeichnung der Konventionen und unterschiedlichen Klassen werden hier beschrieben. Die Ergebnisse der Experimente und Umfragen wurden untersucht, die Erfolge und Misserfolge der verschiedenen Wurzelsperren beschrieben und Richtungen für künftige Forschung festgelegt.

Resumen. Se presenta una revisión de la investigación en barreras de raíces en los pasados cuarenta años. La investigación resulta de la necesidad de minimizar los conflictos entre la expansión de las raíces de los árboles y las infraestructuras urbanas tales como carreteras, guarniciones, basamentos y servicios subterráneos. Se describe la historia de las barreras de raíces, nombres convencionales y clases diferentes. Se examinan los resultados de los experimentos y encuestas, así como los éxitos y las fallas de diferentes barreras y se sugieren las direcciones para futuras investigaciones. 